Vol. XXI - REVISTA DE HISTORIA - Ano XI

\title{
CONFERENCIAS
}

\section{MARTIM CABRAL, O BÓLIDE $\left(^{\star}\right)$.}

No ano de 1869 bacharelou-se em Direito pela tradicional Academia de São Paulo, o jovem Martim Cabral Moreira dos Santos, de infeliz e desafortunado destino. Morreu dois anos depois de formado, sem poder se realizar e sem de si deixar o rasto que seus dotes intelectuais um dia pressagiaram. Relembrado é êle apenas por meia dúzia de ensaistas e na evocação que dos tempos de Academia traçaram alguns de seus contemporâneos, e assim mesmo apagado de todo estaria o seu nome se um daqueles contemporâneos que o evocaram não se chamasse Rui Barbosa. Na própria cidade paulista onde viveu e morreu, e que foi Pindamonhangaba, e onde uma via pública ostenta o seu nome, Martim Cabral é hoje apenas uma rua, desconhecido de todos, sòmente recordado por alguns poucos cultores da história local, que nada sabem do que teria escrito ou publicado.

Foi o eminente jurisconsulto baiano Rui Barbosa, o autor da epígrafe que serve de título ao presente escôrço históricobiográfico. Quando em 8 de dezembro de 1886, na homenagem fúnebre realizada no antigo Teatro de São José, na cidade de São Paulo, em memória do estadista liberal José Bonifácio, o Moço, Rui Barbosa, já então vulto de projeção nacional, em discurso notável e de grande retumbância, recordou alguns dos colegas da Academia que com êle tomaram parte no famoso banquete político oferecido em 1868 ao mestre de Direito Civil e parlamentar liberal, que foi José Bonifácio. Disse aí Rui Barbosa:

"Entre as reminiscências do meu curso jurídico nesta cidade, nunca se me desfará da lembrança a recepção com que o acolheu (a José Bonifácio), depois do golpe de estado de 16 de julho, a juventude acadêmica de 1868 , em um banquete político de grandes proporções, que assinalou data na memória de quantos o celebramos; Joa-

(*). - Conferência pronunciada no Instituto Histórico e Geográfico de São Paulo, em sessão de 6 de abril de 1957 (Nota da Redação). 
quim Nabuco, o futuro orador do abolicionismo, ponto radiante que já se destacava na corôa solar do nome paterno; Barros Pimentel, merecimento dos mais puros, envolvido tenazmente pela sua modéstia em um casulo de sêda; Martim Cabral, grande bólide fulgurante, que se perdeu no horizonte da tribuna brasileira; Gaviáo Peixoto, um dos testamenteiros morais de José Bonifácio; Salvador de Mendonça, o publicista do "Ipiranga"; Américo de Campos, o estoico; Américo Brasiliense, temperamento americano alienado para a república pela rotina pervicaz da monarquia; F. de Meneses, um folhetim vivo, o boêmio da esperança, o fundador da "Gazeta da Tarde"; Castro Alves, o poeta dos escravos" (1).

Destarte, ao lado de Joaquim Nabuco, de Sancho de Barros Pimentel, de Gavião Peixoto, de Salvador de Mendonça, de Américo de Campos, de Américo Brasiliense, de Ferreira de Menezes e de Castro Alves, todos nomes estelares, por demais conhecidos dos cultores da história nacional, ao lado dêles Rui Barbosa alinhou Martim Cabral, definindo-o como

\footnotetext{
"grande bólide fulgurante que se perdeu no horizonte da tribuna brasileira".
}

Alusão à vida breve e aos dotes oratórios brilhantemente demonstrados por Martim Cabral durante os tempos de estudante de Direito.

Esse refulgente epíteto impressionou, calou e produziu reflexos que são as referências que ao malogrado bacharel podem ser encontradas nos historiadores dos fastos da Academia de São Paulo. Assim, em Spencer Vampré (2), que o incluiu entre os que

\section{"amanheceram na Academia no ano de 1868",}

dêle dizendo que fôra

"ardente orador e denodado republicano, que se bateu, na tribuna e na imprensa, ao lado de Francisco Glicério, Américo de Campos, Américo Brasiliense, Rangel Pestana e outros, e constituiu, na frase de Rui Barbosa, - "grande bólide fulgurante, que se perdeu no horizonte da tribuna brasileira".

\footnotetext{
(1). - Rui Barbosa, Ensalos Literários, Gráfica Edtốra Brasileira Ltda., Rioo de Janelro, 1949, págs. 64 e 65.

(2). - Spencer Vampré, Memórias para a História da Academia de sáo Paulo, Saratva \& Cía. Editôres, Săo Paulo, 1924, 2.0 vol., pág. 204.
} 
Também Carlos Penteado de Rezendo (3), recordou o então quintanista de Direito no seguinte trecho:

"certo dia do ano 1869 circulou pelos "Gerais" da Faculdade de Direito a notícia de que o Gottschalk havia chegado a São Paulo... Cursavam na ocasião a Academia, e poderiam talvez estar no pátio, conversando a respeito, rapazes como os quintanistas Salvador de Mendonça, amigo de Carlos Gomes, e Martim Cabral, já famoso orador...".

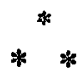

Martim Cabral cursou a Academia justamente no período áureo da escola, quando nela estudaram moços que se chamaram Rui Barbosa, Castro Alves, Joaquim Nabuco, Rodrigues Alves, Afonso Pena e outros que tais.

"Constituiam uma geração trepidante e luminosa, a mais bela geração de moços que já acolhia aquêle tradicional estabelecimento de ensino superior".

como escreveu Vitor de Sá ao biografar Rui Barbosa, incluindo Martim entre os jovens destacados.

Foi a década de 1860-1870 a que maior número de futuras notabilidades viu reunidas na Academia de São Paulo. E Martin Cabral brilhou entre os brilhantes. Esse tempo foi o tempo dos grandes pruridos de liberalismo que recendia a republicanismo e abolição. E Martim Cabral engolfou-se no liberalismo-republicano e pelejou pela abolição. No seu estudo, José Maria dos Santos (5), noticiando a fundação em São Paulo do "Clube Radical", por Luís Gama, Américo de Campos, Bernardino de Campos, Jorge de Miranda, Francisco Glicério, Zoroastro Pamplona, Bernardino Pamplona e Quirino dos Santos, acrescentou:

"A êstes vieram logo juntar-se, como em vibrante e permanente aclamação, os estudantes da Faculdade de Direito. Podemos fàcilmente avaliar o que a adesão dos estudantes representou para a propaganda radical e aboli-

\footnotetext{
(3). - Carlos Penteado de Rezende, Tradiçóes Musicais da Faculdade de Direito de São Paulo, pág. 247.

(4). - Vitor de Sá, Rui e os Constituintes de 91, Rio de Janeiro, Departamento de Imprensa Nacional, 1950, pág. 30.

(5). - José Maria dos Santos, Os Republicanos Raulistas e a Aboliç5o, Livraria Martins, São Paulo, 1942, pág. 52.
} 
cionista sabendo apenas que entre êles estavam Castro Alves, Rui Barbosa, Joaquim Nabuco, Martim Cabral e Salvador de Mendonça".

Naquela década de 1860-1870 fulgiram os grandes oradores da Academia, com Nabuco e Rui à frente. Pois Martim Cabral foi por todos, e principalmente por Rui, apontado como o maior tribuno dentre êles. No ensaio O Patriarca e o Bacharel, Luís Martins escreveu (6):

"A espantosa geração que reunira no mesmo ano em São Paulo as figuras solares de Castro Alves, Rui Barbosa e Joaquim Nabuco, impressionava todos os espíritos com o seu porte excepcional. Entretanto, contam acadêmicos daquele tempo, a maior figura da Faculdade, que empolgava a multidão de estudantes com seu verbo eloqüente e romântico, era Martim Cabral".

E ao registrar a notícia do falecimento, em sua História da Civilização Paulista, disse Aureliano Leite (7):

"Falece em Pindamonhangaba o jovem republicano Martim Cabral, que deixara na Faculdade de Direito a fama do maior orador, até então".

Extraordinário tribuno deveria ter sido, para alcançar a fama de maior entre os maiores!

Naquela época porfiavam os gigantes da tribuna na emulação pela fluência e eloqüência, sendo tudo motivo para torneios de oratória, desde as questões sociais, religiosas e de patriotismo até mesmo as coisas de Direito... Porque a verdade manda que se diga: os acadêmicos de maior prestígio, os de renome, os mais inteligentes, não eram assíduos às aulas. Preferiam êles debater a jurisprudência em sessões mais literárias do que doutrinárias, nos grêmios e associações ou mesmo nas casas dos lentes ou de pessoas de projeção na cidade, quando então à literatura associava-se a arte, o direito, a música, o mundanismo. Lê-se na Imprensa Acadêmica (8):

"Culto à Ciência - Sessão hoje às 11 horas no lugar do costume. Continua a discussão da tese do sr. Matoso sôbre delito falho. Estão com a palavra os srs. Campos, Martim Cabral e Barros Pimentel".

(6). - Luís Martíns, o Patriarca e o Bacharel, Livraria Martins Editôra, São Paulo, 1953, pág. 34.

(7). - Aureliano Leite, História da Civilizaçáo Paulista, Livraria Martins Editôra, São Paulo, pág. 112 .

(8). - Imprensa Acadêmica, n. $0^{4}$, ano 2, 11 de junho de 1866. 
Para comemorar a data da Independência do Brasil, houve em 7 de setembro de 1868 uma "Sessão Magna", às 6 horas da tarde no "Ginásio Literário", encerrando-se às 8 horas da noite. Oraram nada menos do que doze acadêmicos, cada um pelo seu respectivo grêmio, ou associação, ou jornal. Martim Cabral, então quartanista, falou pelo "Acadêmico". Os outros discursadores chamavam-se Leôncio de Carvalho, Brasílio Machado, Joaquim Nabuco (na época assinando-se "Nabuco de Araújo"), Carvalho Moreira... Como de costume, Castro Alves recitou uma de suas magníficas poesias. Quando em 1868 realizou-se o atrás citado banquete político oferecido a José Bonifácio, autor, no Rio de Janeiro, da moção liberal cuja resposta foi a dissolução da Câmara dos Deputados Gerais com a subida ao poder do Partido Conservador, o orador oficial escolhido pelos acadêmicos foi Joaquim Nabuco. E depois da resposta do homenageado seguiu-se uma longa série de intermináveis brindes, noticiada pelo jornal A Imprensa Acadêmica (9), na secção "A Pedido", pois que, diga-se de passagem, êsse órgão dos acadêmicos era imparcial, nem liberal nem conservador. $\mathrm{Na}$ longa série não faltou o nome de Martim Cabral, com dois brindes, assim descritos pelo articulista:

"O sr. Martim Cabral ao conselheiro José Bonifácio, êsse homem que à frente daqueles cujas vozes são o hino mais esplêndido, cuja voz tem ecoado na terra dos Andradas em prol das liberdades públicas, deve ser considerado como a encarnação do partido liberal entre nós".

E o outro:

"O sr. Martim Cabral saúda a ilustre Assembléia Provincial de São Paulo, que saberá cumprir briosamente o seu dever".

Depois dêsse banquete, como que ainda não satisfeitos pelo extravazamento dos sentimentos de repulsa aos conservadores e escravocratas, os acadêmicos realizaram no "Ginásio Literário" uma "Sessão Magna", na qual tiveram a palavra, segundo narrou José Maria dos Santos (10), os senhores José Francisco Diana, Martim Cabral, Fernando Osório, Brasílio Machado, Alves Cruz, Leôncio de Carvalho e Monteiro de Barros,

"todos a verberar com fôrça o grave atentado contra os sentimentos da Nação e os direitos de seus represen$\therefore$ tantes eleitos".

(9). - Número de 3-IX-1868.

(10). - José María dos Santos, op. cit., pág. 59. 
E, ajuntou José Maria dos Santos,

"onde a emoção chegou realmente ao áuge foi quando se levantou Castro Alves e recitou "O Navio Negreiro". No ambiente profundamente sensibilizado daquele instante, imagine-se o efeito daqueles versos certamente maravilhosos, a clamar na sua espantosa torrente de harmonia todos os sofrimentos, todos os martírios e tôdas as vergonhas da imensa e secular iniquiidade da escravidão! As notícias da festa, com os versos do poeta, espalharamse ràpidamente por tôda parte. O Brasil inteiro, entre compungido e transportado, recitava "O Navio Negreiro".

A guerra do Paraguai, que ocorreu justamente naquela década, isto é, de 1865 a 1870 , foi outro motivo para a expansão dos ardores cívicos estudantis, entregando-se todos às arengas inflamadas e exaltadas. O mestre de Direito Martim Francisco Ribeiro de Andrada, o Moço, Martim Cabral, então primeiroanista, e mais dois outros acadêmicos, Miguel de Godoy Moreira e Costa e José Monteiro Machado César, foram os que saudaram, numa festa realizada em São Paulo, em 18 de outubro de 1865 , os primeiros Voluntários oriundos de Pindamonhangaba e Taubaté, destinados ao Sul, ao teatro das operações bélicas. Noticiou um jornal de São Paulo, em transcrição feita pelo pindense Ataide Marcondes no seu livro Pindamonhangaba através de/dois e meio séculos. 1672-1922 (11):

"As comissões de Pindamonhangaba e Taubaté foram saudadas com vivo entusiasmo; os eloqüentes discursos dos inteligentes Acadêmicos os srs. Miguel de Godói Moreira e Costa, José Monteiro Machado César e Martim Cabral, honraram o lugar que os viu nascer; provaram mais uma vez que são destinados a um dia representarem na sociedade um papel brilhante".

$\mathrm{E}$ foi por ocasião do término da guerra, quando regressou do Paraguai o batalhão de Voluntários de São Paulo, o $35 .^{\circ}$, composto dos remanescentes de outros, que Martim Cabral pronunciou, a 27 de abril de 1870 , uma de suas mais empolgantes orações, parece que escrita, porquanto saiu publicada nos jornais da época, inclusive no "Pindamonhangabense" e principalmente no "Correio Paulistano", de São Paulo (12). Do acontecimento deu notícia Aureliano Leite da seguinte forma (13):

(11). - Ataíde Marcondes, Pindamonhangaba através de dois e meio séculos, 1672-1922, 2a. edíção, comemorativa do Centenário :da Independêncía do Brasil. São Paulo, 1922, pág. 212.

(12). - Ano XVII, n.o 4143, de sábado, 30 de abril de 1870.

(13). - Op. cit., pág. 110. 


$$
\therefore \quad=295 \text { - }
$$

"Aọ .25' de abril -(de 1870), regressa do-Paraguai o $35 . .^{\circ}$ de Voluntários, formado dos remanescentes do $7.0 \mathrm{e}$ 42.. batalhões. Numa, das festas em regozijo, que duram uma semana, ora o bacharelando Francisco de Paula Rodrigues Alves, que termina colocando uma corôa de louros na bandeira daquele batalhão. Oram também outros tribunos da época, como Joaquim Xavier da Silveira, Martim Cabral Moreirã dos Santos e Brasílio Machado".

Eis, na íntegra, transcrita do jornal "Correio Paulistano", $n{ }^{\circ}$ de 30 de abril de 1870 , a oração condoreira, no tipo e no estilo do versejar de Castro Alves:

"Discurso do sr. Màrtim Cabral - Damos abaix́o o belíssimo discurso que no espetáculo de quarta-feira, oferecido aos voluntários pelo corpo do comércio, proferiu o eloqüente e considerado sr. dr. Martim Cabral, incontestàvelmente uma das glórias da mocidade atual:

Voluntários Paulistas!

Nós estamos aqui para vos saudar, para saudar essas blusas modestas onde dormiram nossas vidas e viveu a nossa Pátria! O pêso de vossas glórias é demasiado para êste povo - é necessário reparti-las com a Pátria, reparti-las com a posteridade! Hoje, nós os brasileiros, nós os paulistas, podemos morrer, porque sôbre nossos túmulos a posteridade há de ver de pé vossas estátuas - as estátuas da imortalidade!

A auréola do triunfador brilha tanto em vossas frontes, que ela apagaria a luz de nossos olhos. Vêde esta multidão brilhante que se debruça sôbre as galerias e com respeito mede as vossas frontes; vêde êste povo que se levảnta como uma só voz e enche a imensidade com seus vivas; escutai, voluntários, todos os lábios estalam em vossas faces o beijo da gratidão, como os vossos lábios estalaram na bandeira da Pátria o beijo da Vitória!

Contemplando-vos face à face, nós nos lembramos da campanha; dêsse abismo onde parecia que iam naufragar nossas vidas, nossas tradições e nossas esperanças; dêsše vulcão onde as lavas da tirania se alimentaram por tanto tempo com o sangue das vitimas; dêsse oceano onde os náufragos da tormenta eram os mártires da bravura!

A história dessa campanha teve momentos horriveis! Quantas vêzes no meio do campo não oscilou o pếndulo da vida, parecendo estacionar?

Quando o toque da corneta, para apressar vossos golpes estalava como um grito de maldição em vossos ouvidos, parecia se ouvir no meio daquele rumor confuso êste eco triste: - "Ai dos vencidos!...". 
Quando as balas percorriam vossas fileiras como linguas de fogo que iam tudo incendiar, era em vossos corações que refluia todo o sangue da Pátria; vossas baionetas se elevavam no ar e eqüilibravam a vida; vossos braços se estendiam como para-raios no meio dessa tempestade de fogo e enquanto a Morte se vitoriava sôbre milhares de cadáveres, o patriotismo soprava em vossos fôlegos a vida dos heróis!

E depois... quando o canhão emudecia receando despertar aquêles bravos; quando a Morte vestida de sangue fazia sua retirada sinistra nas ondas de fumo que iam se dissipando pouco a pouco; então, sôbre cada bravo que morria havia um soldado que chorava!

$\mathrm{Oh}$ ! como deviam ser tristes essas noites em que a única estrêla que brilhava era uma lágrima! Voluntários Paulistas! nós saudamos essas estrêlas que cairam de vossos olhos.

Voluntários! Hoje o que vos resta? Essa bandeira que envelheceu no meio de vossa bravura, que por onde passava conquistava corôas de triunfo, está fechada com os "sete sêlos" do govêrno!... Vosso batalhão vai ser dissolvido - vossas fileiras vão ser retalhadas!

Dispersos aqui, separados além, tranqüilizai-vos voluntários; vós haveis de estar todos unidos em uma só imagem no coração do Povo: nesse altar há de haver uma saudação eterna ao patriotismo que nos salvou em tantas batalhas; à constância que vos legou a palma do heroismo, e ao heroismo que vos deu a chave da imortalidade.

E quando, voluntários, tiverdes de despir vossas blusas, para ganhar com o suor do trabalho o pão que não pudestes ganhar com o sacrifício de vosso sangue, sacudi bem sôbre a cabeça de vossos filhos a poeira dessas blusas e dizei-lhes: - herdeiros da vitória e da imortalidade - eis aqui os restos do patriotismo!

Mas é cêdo! Esta multidão ainda quer prestar as últimas homenagens a essas fardas onde se aquartelou o patriotismo; a essas fardas que salvaram a dignidade de uma Nação, a vida de um povo, e que não podem garantir nem a vida, nem o futuro de um soldado! Escutai voluntários paulistas: êste Povo vai rolar no espaço seus aplausos: - Vivam os Voluntários Paulistas!!!".

Atente-se para o período final: é um ataque ao govêrno conservador, que ia dissolver o batalhão, pura e simplesmente, sem cuidar do futuro dos soldados.

O pindense Ataíde Marcondes (14) também transcreveu a oração e informou que a mesma saiu publicada em princípios (14). - Op. cit., pág. 369 . 
dêste século no "Jornal do Comércio" do Rio de Janeiro, sendo, entretanto, atribuída a Xavier da Silveira. O eqüívoco é muito grande. Xavier da Silveira de fato orou por ocasião dos festejos comemorativos da chegada dos Voluntários da Pátria a São Paulo e seu discurso foi publicado pelo "Correio Paulistano" de 13 de maio de 1870. Mas, ao invés de saudar os soldados, êle fôra por êstes justamente incumbido de agradecer as homenagens prestadas pelo "corpo acadêmico", isto $\dot{e}$, pelos estudantes de Direito.

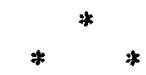

A década de 1860-1870 também foi fértil quanto ao lançamento de jornais äcadêmicos ou não. Segundo estatística, no ano de 1860 circulavam na cidade de São Paulo 16 periódicos, além de funcionarem 10 sociedades literárias! Pois desde 1865 , quando ingressou na Escola, até 1869, quando se formou, encontra-se o nome de Martim Cabral entre os redatores de quase todos os jornais aparecidos, pelo menos de todos os mais importantes, excetuados os de feição conservadora. Cumpre notar que tais periódicos eram geralmente de curta e efêmera existência, morriam com a aproximação das férias escolares ou com a formatura dos componentes do corpo redatorial. Raros passaram dos primeiros números.

Também em Pindamonhangaba o estudante Martim Cabral realizou jornalismo, colaborando nas fôlhas da terra, que se intitulavam, no seu tempo, "O Progresso" (1863-1866) e o "Pindamonhangabense" (1866-1872).

Em São Paulo seu nome incluiu-se entre os fundadores e redatores de vários jornais, tais como "A Tribuna Liberal" (1867), lançada por êle conjuntamente com Joaquim Nabuco, Salvador de Mendonça, Artur Carvalho Moreira, Ferreira Braga Júnior, Leôncio de Carvalho, Monteiro de Barros, Pereira de Campos e Clímaco Cesarino; "A Independência" (1868), jornal político e literário que tinha por lema famosa divisa britânica ("Honny soit qui mal y pense"), redigido por êle e mais Castro Alves, Rui Barbosa, Pimenta Bueno, Carvalho Moreira e outros; "O Acadêmico" (1868), jornal jurídico, literário e noticioso, que teve como "diretores de redação" Leôncio de Carvalho e J. F. Diana, e como redatores Aureliano Coutinho, Aureliano Mourão, Fernando Osório, Martim Cabral, Machado Lima, Pires Maciel, Rubino de Oliveira, Santos Malheiro, Silva Tavares, Teixeira de Carvalho, Teixeira da Mota e Vicente de Toledo, todos êsses nomes constando da relação no cabeçalho 
do jornal, que foi, por sinal, um dos melhores da época. "O Radical Paulistano" (1868), órgão oficial do "Clube Radical Paulistano", êste uma seção do Partido Liberal-Radiçal, então fundado na Côrte, foi redigido pelo famoso negro abolicionista Luís Gama, por Rui Barbosa e ainda por Martim Cabral, os irmãos Pamplona de Menezes - Zoroastro e Bernardino - Américo de Campos, Jorge de Miranda, Bernardino de Campos, Francisco Glicério e Quirino dos Santos. Colaborador ainda de "A Imprensa Acadêmica", que se intitulava o "Jornal dos Estudantes de São Paulo", de feitio "literário, noticioso, científico e comercial", dirigido sempre por um quintanista, chamado o "redator-em-chefe", e redigido por uma comissão composta de dois estudantes, representando cada ano escolar, dez ao todo, pois que de cinco anos se compunha, como até hoje, o currículo acadêmico, colaborador dêsse jornal, Martim Cabral viu-se, no seu quinto ano de'Direito, eleito "redator-em-chefe" do órgão da Academia de São Paulo. Noticiando o fato, lê-se no "O Acadêmico", o seguinte (15):

\begin{abstract}
"Eleição - Para redator em chefe da "Imprensa Acadêmica" foi eleito o sr. Martim Cabral, um de nossos colegas de redação. Com êle congratulamo-nos pela distinção com que foi honrado, e da qual é altamente merecedor, e felicitamos a Academia pela acertada e digna escolha que acaba de fazer. O Sr. Martim Cabral, na direção suprema do órgão da Academia, saberá defender os legítimos interêsses da classe e zelar os altos créditos da mocidade acadêmica de São Paulo.

Temos as mais fundadas esperanças de que a "Imprensa Acadêmica" de 1869 há de erguer-se à altura da corporação que representa, e das tradiçōes gloriosas da Academia".
\end{abstract}

Como se vê, por eleição, Martim Cabral foi escolhido para o mais importante pôsto, o de maior proeminência entre os estudantes da Academia.

Fundado em 1864, suspensa a publicação em 1865-1867 por dissensões políticas, havendo reaparecido em 1868, o órgão da Academia chegou, em certa ocasião, a circular duas vêzes por semana. Entre seus colaboradores contaram-se vultos como Castro Alves, que nele inseriu suas poesias, Rui Barbosa, e outros mais. Para ressaltar a importância da posição alcançada por Martim Cabral, basta que se diga que no ano seguinte, em 1870, findo o seu mandato, a eleição de seu sucessor terminou por um emocionante empate e o resultado foi que dois quinta-

(15). - Número de 24 de outubro de 1868. 
nistas sairam investidos como "redatores-em-chefe". Eram êles Francisco de Paula Rodrigues Alves e Afonso Augusto Moreira Pena, os conselheiros que presidiram a República. Durante a gestão de Martim Cabral, em 1869, Rodrigues Alves e Afonso Pena haviam sido os 'representantes do quarto ano na redação do jornal.

$\mathrm{Da}$ importância que representava para o escolhido a direção do órgão da Academia, informaram Estevam Leão Bourroul e João Mendes de Almeida quando biografaram Rodrigues Alves. Disse o primeiro (16):

"era a honra mais elevada a que podia aspirar um acadêmico, pois constituia-se destarte o diretor intelectual da Mocidade".

E disse o segundo (17):

"cargo que só a eleição de numerosos colegas poderia deferir e de fato deferia aos mais conhecidos por seus talentos e estudos".

O primeiro artigo de fundo escrito por Martim Cabral como dirigente do jornal valeu-lhe o recebimento de duas cartas, uma do então acadêmico João Monteiro, o depois afamado mestre de Direito Judiciário João Pereira Monteiro Júnior, e outra de Francisco Inácio Marcondes Homem de Melo, futuro barão Homem de Melo, que presidiu a província de São Paulo e foi ministro do Império.

Eis, na íntegra, o referido artigo (18):

"A Imprensa Acadêmica" é a palavra dos moços, a expressão de seus sentimentos e de suas idéias. Se essa palavra vai ter um eco no meio do tumulto da atualidade, se ela vai interromper o concêrto horrível da indiferença literária e das paixões dos partidos, o futuro é quem há de dizer.

A mocidade sente necessidade de falar, e fala, sente necessidade de escrever e escreve: mas sufocar a palavra nos lábios, temendo que ela caia no seio da sociedade mais fria do que o gêlo dos montes, quebrar a pena receando que ela se abrase no fogo das paixões políticas e creste tôdas as esperanças literárias, como tem crestado as veias mais palpitantes do corpo social; é não compreender o destino, é rebelar-se contra a lei de tudo que deve viver, é suicidar-se como o guerreiro que encruza os braços diante do inimigo, porque não sabe quem há de vencer.

(16). - Arquivo Ilustrado, novembro de ' 1900.

(17). - J. J. Ribeiro, Cronologia Paulista, 2, 2a. parte, pág. 338.

(18). - Imprensa Acadêmica, n. ${ }^{\circ}$ 1, ano III, 24 de abril de 1869. 
Não. A mocidade ainda tem os olhos abertos, o sono pesado do indiferentismo não lhe cerrou as pálpebras, nem o demônio da descrença traçou-lhe nalma a palavra do impossivel; ela acredita na religião, na ciência e na arte, ela caminha para êsses três mundos que constituem o progresso social. Nesse caminho ela quer deixar um traço de sua passagem, e para isso escreve a "Imprensa Acadêmica"; é o fio de Ariadne que lhe há de servir para romper as trevas em que seus olhos giram incertos, e abrir no seio delas um sulco de luz por onde possa avistar o belo que é o ideal da arte, a verdade que é o ideal da ciência, Deus que é o ideal da religião.

"A Imprensa Acadêmica" é um jornal puramente literário, entre os dois princípios que dividem os partidos a supremacia dos povos e a supremacia dos reis, ela simboliza a neutralidade, surge no meio dêles como um prumo cujo ponto de apôio é o sol das letras; ela vai substituir o estudo das evoluçóes dos partidos pelo estudo das idéias: a Grécia pela filosofia, Roma pela liberdade, o Papa pelo cristianismo.

A história, o livro do passado, êsse livro onde cada povo tem uma página, a literatura o império do belo sôbre os costumes sociais, a filosofia a soberania do pensamento, o direito a realeza do cidadão, a religião a alma do mundo, eis aí o Horeb sagrado da mocidade.

Ela não há de olvidar um só esfôrço para galgar essa montanha, e quando um dia, embora muito remoto, o tiver conseguido, então com os pés descalços e com a cabeça descoberta, ela há de saudar a pátria como Moisés ao avistar o anjo de Jeová saudava a libertação de Israel.

$\mathrm{Na}$ crítica literária e histórica a "Imprensa Acadêmica" se intitulará a imparcialidade, na filosofia a liberdade, no direito a justiça, na religião a tolerância.

A missão da imprensa hoje em nosso país é bastante pesada, sejamos francos, não somos pessimistas, mas a indulgência em excesso é uma cumplicidade: tôdas as instituições estão estragadas, elas têm um inimigo muito forte a combater - é o egoísmo; êle surge de tôdas as partes, na indústria agrícola, na indústria comercial, na indústria fabril, em tudo que é instituição: êle lisonjeia os instintos do homem, êle é a morte do espírito - o bezerro de ouro passa em seu carro triunfante no meio dos aplausos de todos, gela os sentimentos, os mais elevados da natureza humana e como um espectro afugenta do coração da juventude o entusiasmo literário. Uma propaganda contra o predomínio do industrialismo sôbre a instrução popular, eis a missão da imprensa em nosso país, eis também qual deve ser a palavra dos moços. 
Não desanimemos, o materialismo concentra tôda sua fôrça na matéria, mas a matéria passa e sôbre suas ruinas o espírito há de achar-se sempre de pé.:

O império das letras, a instrução, a circulação das idéias, como base e fim de tôdas as instituições, eis a verdade de que todos estão convictos, mas que está bem longe da realidade: ela surge como uma visão entre os vapores da civilização moderna: é necessário dar-lhe um corpo, construir-lhe um altar, entoar-lhe um hino.

Então o progresso há de ter uma base sólida, o corpo há de viver, o espírito há de reinar, todos os homens hão de assentar-se no banquete da inteligência, a discussão há de ser uma festa popular.

O carpinteiro, o pedreiro, o alfaiate, em uma palavra, todos os operários hão de ir conversar nas praças sôbre os interêsses de suas classes.;

O lavrador, o manufatureiro, o comerciante hão de ter os olhos presos nos lábios dos oradores, compreendê-los, reparar talvez os erros da tribuna, tomar um lugar no meio dos representantes do povo, legislar sôbre a emigração, a escravidão, os impostos e tudo seguirá sua marcha natural

O poder desta transformação está na imprensa, especialmente em nosso país onde não há universidades nem bibliotecas abertas à avidez do espírito.

Mas com que direito a mocidade toma a palavra para discutir os grandes problemas que o século agita? Com que direito quando ela não tem ainda a fronte cingida pela corôa do sofrimento para compreender as dores da pátria? Com que direito se ela não tem ainda os passos firmes, porque falta-lhe o cetro da experiência?

E' por tudo isso mesmo que ela trava da pena.

E' porque a pátria sofre que ela quer também sofrer, preparar-se para os golpes de amanhã.

E' porque não possui a experiência que ela fala e escreve para adquiri-la, expõe com lealdade o seu modo de pensar para que os homens de hoje descansem na fé e na inteligência dos homens de amanhã, saibam que não são moços sem vida que vão substitui-los, tomar suas armas para continuar o combate do século.

E por que a mocidade não há de falar? Cava-se o passado e êle tem uma voz, é a tradição, respeita-se. Estuda-se o presente e êle tem uma alma, é o trabalho em tôda sua atividade, a lei em todo seu vigor, a instituição em todo seu brilho: obedece-se.

Por que não se há de consultar o futuro?

Sim, a mocidade deve falar, o futuro tem um eco, é o pressentimento. 
No Egito, em Roma, se consultava o vôo das aves, elas soletravam em seus cantos os hieróglifos das pirâmides, varriam com suas asas a poeira dos livros sibilinos: hoje é o reinado da luz, nossas pirâmides são as Academias, nossos hieróglifos a publicidade da imprensa: a ave do futuro é a mocidade. Suas asas são idéias, sentimentos, religião, pátria, família, tudo que há de grande na vida dos povos, de imortal nas tradiçôes dos séculos.

A mocidade não é pretenciosa, ela tem consciência de que sua palavra não é uma lei, mas há de repetí-la até que ela se eqüilibre entre os rumores do espaço, e quando um dia surgir uma nova éra, quando um dia rasgarse a cortina do futuro, ela poderá talvez escrevê-la no evangelho da pátria, na cruz da religião, no lar da familia".

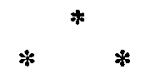

A propósito do artigo supra-transcrito, João Monteiro dirigiu uma longa carta ao "redator-em-chefe" (19). Depois de modestamente dizer que não possuia capacidade para escrever algumas linhas para o jornal e assim satisfazer ao pedido do amigo, insurgiu-se contra a neutralidade pregada por Martim no seu artigo de fundo. E qualificou a neutralidade de filha da fraqueza ou da deslealdade, ao mesmo tempo que defendeu e exaltou o articulista no seguinte período:

"Fraco, não posso julgar-te: seria preciso fechar os ouvidos ao eco imponente de tua palavra, seria preciso fechar os olhos aos escritos de tua pena. Desleal? Mas a chama augusta da democracia levanta-se em teu seio; a idéia sagrada da liberdade de teus irmãos cativos pulula-te na fronte, à espera do grande dia da emancipação para saltar brilhante como uma auréola à tua cabeça de brasileiro; mas se amas e respeitas o Evangelho do Cristo em tôda a sua sublimidade e essência, limpo da poeira dos séculos que têm passado sôbre êle!' Não, não podes ser desleal".

E conclama

"a que a "Imprensa" diga a verdade ao povo", repelindo a "fatal proclamação da neutralidade, proclamação que, repito, não posso acreditar que respeites".

(19). - Imprensa Acađêmica, n. 2 de $10^{\circ}$ de maio de 1869. 
Digno de nota é o seguinte conceito de João Monteiro, que enunciou a propósito da paciência do povo em aturar as tiranias:

"o povo espera, e quando o povo espera é como o tigre a espreitar o momento de atirar-se à vitima...".

A carta de Homem de Melo, ainda sôbre o mesmo artigo de fundo, precedida de um exórdio da autoria de Martim Cabral, foi publicada na referida "Imprensa Acadêmica". Ei-la (20):

"Carta particular - Abaixo transcrevemos uma carta dirigida pelo distinto historiador brasileiro o Ilmo. sr. dr. Homem de Melo, ao redator em chefe da "Imprensa Acadêmica".

Ele, o "moço historiador", que tem galgado as mais brilhantes posições sociais, não se esqueceu da mocidade; com aquela mesma eloqüência com que anima os grandes vultos de nosso passado, e expõe à admiração da posteridade as glórias da pátria, êle acende no coração da mocidade o entusiasmo pelas letras, anima a nós, fracos lidadores, para que não nos deixemos abater diante da responsabilidade do futuro.

Esta carta é uma recompensa suficiente ao nosso trabalho, porque ela servirá para preservar a "Imprensa Acadêmica" do indiferentismo da época, e chamar a atenção do pais sôbre a mocidade de São Paulo.

Meu colega.

Venho saudá-lo em meio de seus triunfos e das esplêndidas esperanças, que the sorriem no futuro. Em o primeiro número da "Imprensa Acadêmica", que ora tènho sob os olhos, leio:

" $E$ ' porque a pátria sofre, que ela (a mocidade) quer também sofrer, preparar-se para os golpes de amanhã. E' porque não possui a experiência, que ela fala e escreve para adquirí-la, expõe com lealdade o seu modo de pensar, para que os homens de hoje descansem na fé e na inteligência dos homens de amanhã, saibam que não são moços sem vida que vão substituí-los, tomar suas armas para continuar o combate do século".

A mocidade compreende a sua responsabilidade perante o futuro, perante a causa da pátria. Há de desempenhá-lo. E' a nossa esperança, e também a nossa consolação. Já muito tempo perdeu-se, sem que esta geração

(20). - Imprensa Acađêmica, n.o 4, de 15 de maio de 1869. 
mostrasse possuir virilidade bastante para superar os assombrosos acontecimentos, que se consumam. Siga a mocidade essas tradições de honra, que ela encontrou no seio do passado, e que ora invoca com fervor.

Venham êsses novos companheiros dominados pela pureza de sentimentos, vigorados por uma fé robusta, tomar parte na luta. Eles farão alguma coisa melhor do que esta incerteza do presente, e esta pavorosa vacilação da fé pública no futuro do país.

Precisamos hoje de muito patriotismo, muita energia cívica, muita severidade, para empregá-los no serviço do pais.

Nesse empênho eduque-se a mocidade, compenetrando-se da augusta missão, que lhe está reservada. Com um coração puro, com a inteligência vivificada pelo fogo sagrado do amor da pátria, os moços podem contar que farão uma grande obra, e que triunfarão afinal. Eis porque acompanho com estremecimento êsse tumultuar de idéias nobres, essa agitação pacífica e fecunda, que representa a "Imprensa Acadêmica".

Aceite a saudação do

Seu irmão de letras

Homem de Melo

Rio: de Janeiro, 7 de maio de $1869 "$.

Outros números da "Imprensa Acadêmica", do ano de 1869, inseriram colaboração de Martim Cabral, como aquela na qual êle pregou a "Reforma Acadêmica" e propugnou pela extinção, nas Academias, dos "conventos de uma só regra".

Ainda no número de 24 de abril de 1869 , publicou o gaúcho Fernando Osório, filho do general Osório e jurista eminente, que morreu como ministro do Supremo Tribunal Federal, um artigo de louvor e contentamento pelo renascimento da "Imprensa Acadêmica", elogiando e exaltando a juventude acadêmica do passado e do presente, referindo-se a esta nos seguintes têrmos: - essa juventude

"é no presente Castro Alves descobrindo a linguagem dos deuses. E' Joaquim Nabuco, é Meireles, é Salvador de Mendonça, moços distintos e crentes identificando-se com os sofrimentos do povo. E' Aureliano Coutinho, caráter nobre, estudando no silêncio de seu gabinete as instituições de seu pais, com os olhos prescs no futuro. E', finalmente, Martim Cakral, qual novo Moisés, colocando-se à frente da mocidade, escrevendo no espaço — trabalho, conquista, glória!". 


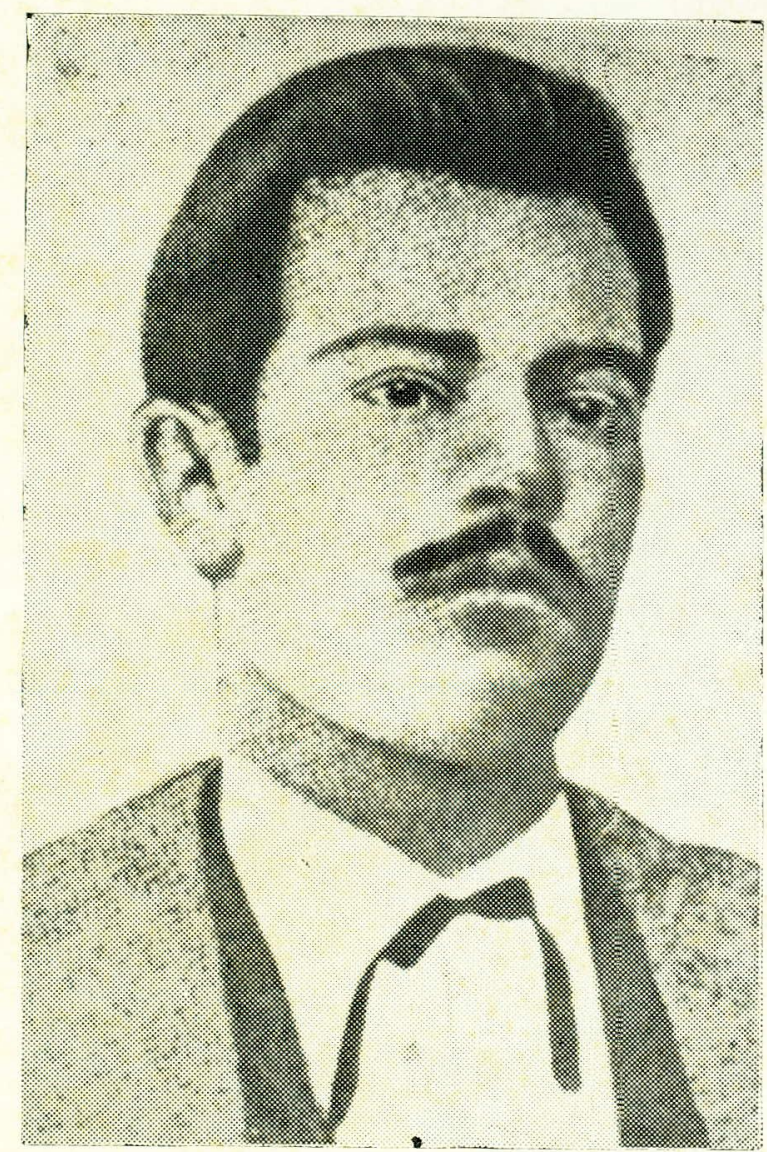

Fig. 1. - Martim Cabral Moreira dos Santos.

Um dos maiores oradores da velha Academia de Direito de São Paulo. 


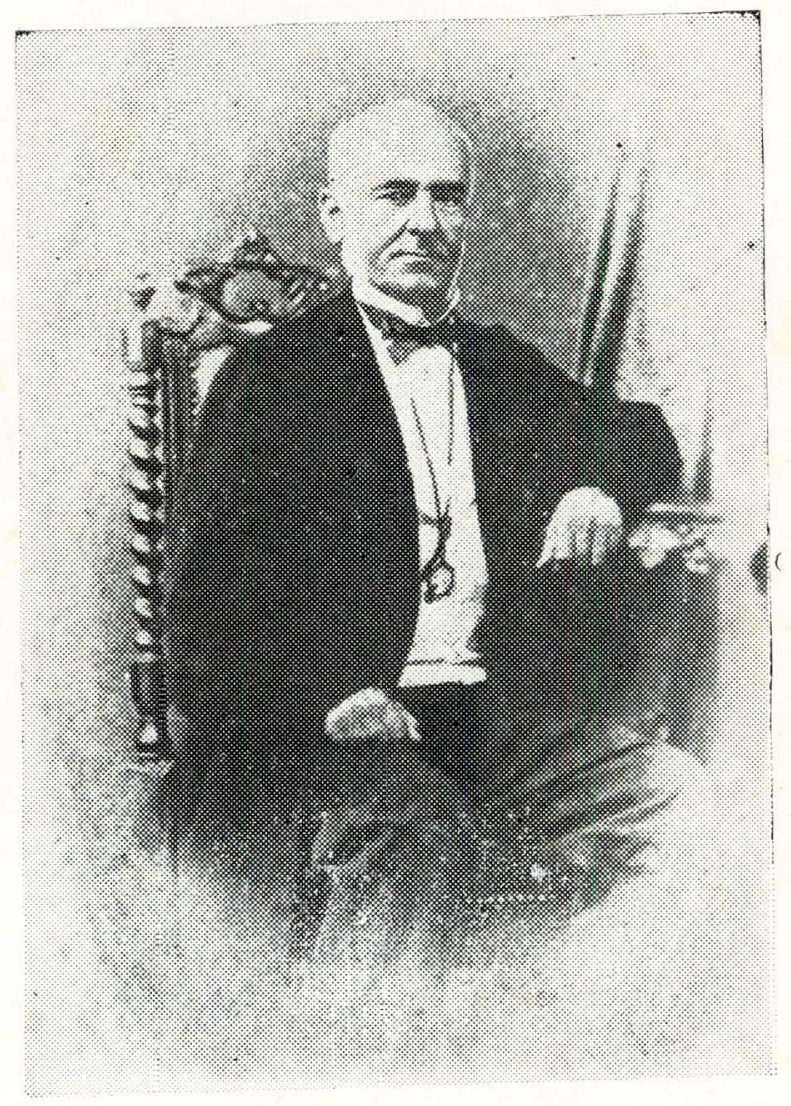

Fig. 2. - Antônio Clemente dos Santos.

Deputado geral e provincial paulista. 
O celebrado Martim Cabral foi registrado no livro que a "Comissão de Restauração do Arquivo da Faculdade de São Paulo" organizou em 28 de março de 1885, para substituir o que fôra queimado no malsinado incêndio de 1880; foi registrado, o celebrado Martim Cabral, como natural de São Paulo e filho de pais incógnitos.

Bastante chamuscados, salvaram-se do incêndio os papéis do infeliz e desafortunado jovem, hoje reunidos na pasta $n .^{\circ}$ 1.357 do arquivo da Faculdade de Direito da Universidade de São Paulo. O manuseio e a leitura dêsses papéis demonstram que Martim cursou os preparatórios na Academia paulistana em 1863 e 1864, sendo aprovado "simpliciter" em Francês, Inglês, Latim e História, obtendo "plenamente" em Aritmética e Geometria, Filosofia e Retórica. O requerimento que dirigiu ao diretor da Escola solicitando matrícula no $1 .^{\circ}$ ano do curso de Direito, é do próprio punho, como se exigia, e diz que se achava habilitado, mas não informou nada quanto à naturalidade e filiação. Um documento anexo, de batizado, necessário para a matrícula, é a certidão passada pelo reverendo Tobias da Costa Rezende, padre coadjutor da paróquia de Pindamonhangaba, datado de 27 de fevereiro de 1865 e que transcreve do "Livro de Batizados de brancos n. ${ }^{\circ} 12$ ", pág. 433, da Matriz de Pindamonhangaba, os seguintes dizeres:

"Aos catorze de abril de mil oitocentos e quarenta e seis, nesta matriz, o Reverendíssimo Ignácio Marcondes de Oliveira, batizou e pôs os santos óleos a Martim filho de Rita Ferreira da Silva de Guaratinguetá, Padrinhos o mesmo reverendo batizante e dona Zeferina Marcondes, todos desta paróquia. O Vigário, Antônio Marcondes Godoi de Almeida".

Então, dêsse assentamento concluiu-se que Martim foi batizado em Pindamonhangaba em 14 de abril de 1846, sendo filho de Rita Ferreira da Silva, de Guaratinguetá. Mas, no "Livro n. ${ }^{\circ} 16$ de Batizados", da paróquia de Santo Antônio de Guaratinguetá, pág. 219 V., consta o seguinte:

"Em o ano de mil oitocentos e quarenta e seis, batizou-se na paróquia de Pindamonhangaba a Martim de idade de dois anos, filho natural de Antônio Clemente dos Santos, e de Rita Ferreira da Silva, tendo sido padrinhos Manuel de Moura Fialho, e Dona Zeferina Marcon- 
des dos Santos, e devendo aqui existir êste assento, agora o faço por autorização do muitíssimo e Reverendissimo Vigário geral, Joaquim Manuel Gonçalves de Andrade o por informações de pessoas fidedignas. Aos dezesseis do maio de mil oitocentos e sessenta e cinco. O Vigário Mel. Benedo. de Js.".

Quer dizer que "devendo existir" em Guarantinguetá o assentamento do batizado de Martim, foi êle lançado em 1865 no livro dos batizados lá efetuados entre 1833 e 1855, sendo que as palavras "e cinco", no livro referido, foram evidentemente acrescentadas em data posterior, tal a diferença das tintas usadas. Nota-se ainda que não coincidem os nomes dos padrinhos, nos dois registros.

Mas por que deveria existir o assentamento em Guaratinguetá? Simplesmente porque Martim lá nascera, sendo filho de Rita Ferreira da' Silva, uma pobre hetaira ali residente. Segundo informou Geraldo França Bueno - um estudioso da história guaratinguetaense e autor de alguns artigos sôbre Martim nos jornais locais - êste último nasceu na rua da Pedreira (atual Coronel Tamarindo), numa casa de esquina, junto a um beco antigamente denominado "beco dos Prazeres". Sua mãe, que recebera do poviléu o apelido de "Rita Chuvisco", entregou-o ao pai, ou a tal viu-se obrigada, quando o menino beirava os dois anos. Enviado para a casa de um primo de seu pai, o major José dos Santos Moreira, que foi vereador, juiz de paz e provedor da Santa Casa de Misericórdia de Pindamonhangaba, lá foi Martim criado por sua madrinha, Zeferina, filha do major, de quem tomou o sobrenome "Moreira" ao qual acrescentou o "Santos", do pai. Em Pindamonhangaba cresceu e viveu até 1863, quando foi mandado para São Paulo, para estudar. Em Pindamonhangaba voltou a residir, com a mãe adotiva, no ano de 1870, já formado. Ali exerceu a advocacia, ali enfermou e ali veio a falecer.

E quem foi seu pai? Chamou-se êle Antônio Clemente dos Santos, um figurão de grande projeção em tôda a zona do Vale do Paraíba. Foi comendador da Ordem de Cristo, deputado provincial à Assembléia Paulista por muitas legislaturas e deputado geral por São Paulo à Câmara dos Deputados do Império. Possuiu fazendas em Areias, Lorena, Guaratinguetá e Pindamonhangaba e foi armador em Paratí, segundo asseverou o supra-citado historiador guaratinguetaense Geraldo França Bueno. Residiu em Guaratinguetá, onde foi prefeito, em Areias, em Lorena, onde foi delegado, em São Paulo e no Rio de Janeiro. 
A sua casa em Lorena foi classificada por Emilio Zaluar (21) como digna de

"figurar em qualquer das ruas da capital", juntamente com algumas poucas outras que se distinguiam" "pela grandeza e elegância de construção".

Esse edifício foi posteriormente adquirido pelo barão de Santa Eulália, que nele residiu, como também o seu filho, o antigo presidente da Câmara dos Deputados Federais e senador por São Paulo, dr. Arnolfo Azevedo.

Antônio Clemente dos Santos nasceu em Guaratinguetá em 1803 e aí faleceu em 10 de junho de 1875. Descendia dos primeiros povoadores da terra paulista, sendo filho do guaratinguetaense alferes Antônio José dos Santos (22) e de Benedita Francisca de Miranda. Desde jovem entregou-se à política, tomando parte saliente na Revolução de 1842 (23). Pertenceu sempre ao Partido Liberal, ao qual filiou-se também Martim Cabral. Foi deputado provincial nas 2a., 7a., 8a., 15a., 16a. e 17a. legislaturas e deputado geral na 7a. legislatura geral. Os "Anais da Assembléia Provincial de São Paulo" denotam à saciedade a intensa ação legislativa por êle desenvolvida. Intensa e aguerrida, pois era combativo e ousado e seus discursos e apartes entremostram um indivíduo inteligente e lido. Teve assim Martim Cabral a quem sair...

Antônio Clemente dos Santos casou-se em Guaratinguetá com sua prima-irmã Francisca Marcondes dos Santos, descendente do fundador de Pindamonhangaba, filha que era de Tomaz Marcondes do Amaral (24) e de Maria Antônia dos Santos. Teve dois filhos, um de iseu próprio nome, que faleceu solteiro quando estudava Medicina (informação ainda de Geraldo França Bueno), e a senhora Pórcia Francisca, que foi casada com o médico guaratinguetaense José Manuel de Castro, Santos, deixando descendência. Esses os legítimos, porque naturais, filhos de várias mães, o político do Vale do Paraiba deixou, além de Martim Cabral, para mais de uma dezena, todos por êle

(21). - Emílio Zaluar, Peregrinação pela Província de São Paulo (1860-1861), Ed:ções Cultura, São Paulo, 1943, pág. 80.

(22). - Silva Leme, Genealogia Paulistana, vols. 3 (págs. 71 e 77) e 7 (pág. 386 ).

(23). - De acôrdo com a/ informação de Carlos da Silveira, in Aluísio de Almeiđa, A Revolução Liberal de 1842 (Rio de Janeíro, 1944, pág. 17), na "Relação dos Réus", pronunciados como cabeças dessa rebelião, encontra-se Antônio Clemente, que é o $13.0^{\circ}$ da lista, ao lado de outros próceres, tais como o senador Feijó e o brigadeiro Tobias de Aguiar.

(24). - Silva Leme, op. cit., vols. 3 (págs. 71, 77) e 7 (págs, 361 e 385). 
bem amparados e bem encaminhados, sendo que um foi brigadeiro e comandante das armas da província do Pará.

Senhor que 'foi de grande fortuna, de numerosas fazendas e de copiosa escravaria, calculada em mais de duzentos indivíduos, Antônio Clemente dos Santos não soube ou não pôde gerir bem os seus haveres, e poucos anos antes de morrer perdeu tudo o que possuia, dizem que roubado pelos seus administradores e endividado pelo muito que gastava, quer na política ou quer nas complicações resultantes da vida amorosa que levou.

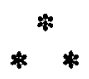

Quando Martim Cabral se transferiu para São Paulo, para fazer os preparatórios, seu pai ali se achava como deputado, e o foi até 1867, ano em que Martim cursou o $3 .^{\circ}$ ano de Direito. Ao formar-se, em 1869, já Antônio Clemente regressara à sua casa de Lorena, onde procedeu ao reconhecimento de Martim como seu filho. Requereu êste ao diretor da Academia, conforme documento no arquivo da Faculdade:

"Martim Cabral Moreira dos Santos, desejando tirar sua Carta, e que nela seja declarado o nome de seu pai, pede a V. Sa. se digne Mandar juntar aos mais documentos que possui na Secretaria da Faculdade, a carta de seu reconhecimento que vai junta a êste. E. R. $M$. (data e assinatura sôbre estampilha verde com a efígie de $\mathrm{Pe}-$ dro II, valor de duzentos réis) São Paulo, 23 de fevereiro de 1870. Martim Cabral Moreira dos Santos".

Ao requerimento juntou o moço a certidão de seu reconhecimento, efetuado em Lorena em 29 de outubro de 1869, dias antes de receber o grau de bacharel em Ciências Jurídicas e Sociais, o que se efetuou em São Paulo, em 15 de novembro do mesmo ano. Está o reconhecimento lavrado nos seguintes têrmos, conforme certidão no arquivo da Faculdade:

"Primeiro traslado da escritura de reconhecimento que passa Antônio Clemente dos Santos, como abaixo se declara.

Pg. de sêlo $\$ 200$.

Saibam quantos êste virem, que no ano do Nascimento de Nosso Senhor Jesus Cristo de mil oito centos sessenta e nove, aos vinte e nove de Outubro, nesta cidade de Lorena, em meu cảrtório, compareceu presente, Antô- 
nio Clemente dos Santos, representado por seu bastante procurador o capitão Manuel Lopes da Silva Castro, residente neste têrmo, e reconhecido de $\operatorname{mim}$ e das testemunhas adiante nomeadas e assinadas; do que dou fé; perante as quais pelo procurador do outorgante foi dito que pela presente, em virtude dos poderes da dita procuração que em seguida a esta vai copiada, passava a escritura de reconhecimento de Martim Cabral Moreira dos Santos, de idade vinte cinco anos mais ou menos, como filho natural do seu constituinte, tido com Rita Claudina das Virgens, no estado de solteira; ficando o mesmo tido e reconhecido como filho de seu constituinte. Pagou o sêlo como me fêz certo pela guia seguinte. Número cinco, Réis duzentos. Por falta de estampilha pagou duzentos réis. Lorena vinte nove de Outubro de mil oitocentos sessenta e nove - Bueno - Camargo - Assim disse e outorgou e me pediu lhe lavrasse esta, a qual sendo-lhe por mim lida aceitou e assinou com as testemunhas presentes Sebastião Hummel e Joaquim José Antunes Braga Júnior, perante mim João de Oliveira Évora, tabelião que a escrevi - Manuel Lopes da Silva Castro - Sebastião Hummel - Joaquim José Antunes Braga Júnior - Nada mais se continha e nem declarava em dita escritura, que assim se achava lavrada no livro de notas quadragésimo quinto, a fôlha vinte cinco que eu tabelião aqui bem e fielmente fiz trasladar como no próprio original constava ao qual me reporto em meu poder e cartório e o presente subscrevo, confiro e assino em público e raso nesta cidade de Lorena, aos vinte nove de outubro de mil oitocentos sessenta e nove. Eu, João d'Oliveira Évora, Tabelião que o subscrevi, confiro e assino em público e raso. E tto. de Verde. João d'Oliveira Évora. Rs 200".

De todos os documentos atrás transcritos não se pode chegar a conclusão exata, provada, do local do nascimento de Martim Cabral. Pindamonhangaba ou Guaratinguetá? Foi em Guaratinguetá, segundo o honesto e desinteressado depoimento dos descendentes de Antônio Clemente dos Santos. E qual o nome exato da progenitora? Rita Claudina das Virgens ou Rita Ferreira da Silva? Talves êste último. Seu apelido foi, como se viu, o de "Rita Chuvisco".

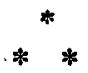

Em 1870 regressou Martim Cabral para Pindamonhangaba, onde dedicou-se às lides forenses, preparando-se, por certo, para disputar cargos eletivos quando chegasse a vez da ascensão 
do Partido Liberal, então no ostracismo, ostracismo que perdurou pelo longo espaço de dez anos. Talvez que o jovem bacharel já tivesse aderido francamente à idéia republicana, que tomava corpo no Brasil em 1870. Os fados não lhe foram propícios, entretanto. Adoeceu em fins do ano de 1871, intoxicado, contam, pelo uso abusivo de um medicamento então em grande voga, o calomelano. Prescrevia-se tal droga principalmente para afecções hepáticas. Sentindo que morreria, teria consolado a mãe adotiva com as seguintes palavras:

"Tenha paciência, minha mãe... O raio não escolhe!" (25).

E morreu 'no dia 18 de dezembro de 1871, conforme reza o assentamento no "Livro n. 5 de óbitos", pág. 10 , verso, da Igreja Matriz de Pindamonhangaba:

"Bacharel Martim Cabral Moreira dos Santos. Aos dezoito de dezembro de mil oitocentos e setenta e um, pelas horas da manhã, tendo recebido todos os sacramentos, faleceu da vida presente, o bacharel em Direito Martim Cabral Moreira dos Santos, solteiro, de idade de vinte e cinco anos, enfermidade do coração, foi sua alma solenemente encomendada, e seu corpo vestido em hábitos ordinários e com grande acompanhamento, foi sepultado em catacumba no cemitério desta cidade. O Vigário Tobias da Costa Rezende".

Seu falecimento repercutiu em tôda a Província, e sentidos necrológios estamparam os jornais paulistas da época. $O$ "Correio Paulistano" (26), noticiou a efermidade e a morte da seguinte forma:

"Lê-se no "Paulista" de Taubaté: Enfêrmo - Achase gravemente enfêrmo o Ilmo. sr. dr. Martim Cabral Moreira dos Santos, formado o ano passado, e um dos talentos vigorosos da nossa província. Fazezmos votos pelo seu pronto restabelecimento".

No número imediato (27), lê-se:

"Dr. Martim Cabral - Ainda na fôlha de ontem, em vista de jornais últimos, do norte da província, noticiávamos que o dr. Martim Cabral estava gravemente enfêrmo,

(25). - Atafde Marcondes, op. cit., pág. 369.

(26). - Número de 22-12-1871.

(27). - Número de 23-12-1871. 
entretanto que já está morto aquêle distinto moço, desde 18 do corrente, conforme carta recente de Pindamonhangaba, recebida também onde nesta capital. E' uma triste noticia. Martim Cabral era uma bela e robusta inteligência que mal principiava a florescer, contando numerosos amigos e admiradores, quer na Academia, onde deixa um nome prestigioso, quer no seio da população desta capital e do norte da província, onde era mais conhecido. Faleceu em Pindamonhangaba para onde fôra depois de alguns anos de residência nesta capital".

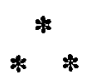

O celebrado Martim Cabral, o bólide fulgurante, mas na verdade o jovem de infeliz e desafortunado destino, foi enterrado na tumba $n .^{\circ} 15$ da quadra $D$ do cemitério de Pindamonhangaba, de propriedade do major José dos Santos Moreira e de outros ancestrais da família que o criara. No jazigo não se inscreveu o seu nome, que apenas consta nos assentamentos do livro do cemitério.

LYCURGO DE CASTRO SANTOS FILHO 